\title{
Community Radios in Portugal: Mapping an Overlooked Alternative Media
}

\author{
Miguel Midões ${ }^{1,2^{*}}$ \\ (iD) 0000-0001-9492-9918 \\ ${ }^{1}$ Instituto Politécnico de Viseu, PORTUGAL \\ ${ }^{2}$ CECS - Centro de Estudos de Comunicação e Sociedade, PORTUGAL \\ ${ }^{*}$ Corresponding author: mmidoes@esev.ipv.pt
}

Citation: Midões, M. (2021). Community Radios in Portugal: Mapping an Overlooked Alternative Media. Online Journal of Communication and Media Technologies, 11(3), e202113. https://doi.org/10.30935/ojcmt/11086

ARTICLE INFO

Received: 11 Sep 2020

Accepted: 7 Jun 2021

\section{ABSTRACT}

In Portugal, community projects that involve broadcasting already appeared in the $21^{\text {st }}$ century. These were linked to the development of the Internet, their primary place of existence, because there were no transmissions for the radio waves in FM.

The Law of Radio in Portugal does not include a third broadcasting sector, which means these community radios were not, officially speaking, community projects. In this regard, how should one look at this? How many radios are there? If they are community projects, what kind of characteristics do they present? These are some of the questions that guide our research and inquiry. Furthermore, it is not easy to move forward with a community definition of radio, as we will see according to some authors.

These community radios represent a change, a new time in which the shared production and the civic participation assume an added importance. Thus, this work's focus is to create a paradigm of criteria that will allow us to analyze and classify the Portuguese community radios, based on an extensive bibliographical research.

Keywords: community media, community radios, civic participation, broadcasting

\section{INTRODUCTION}

To date, there are no studies in Portugal exclusively dedicated to community radios (CR), as far as we know. In general, regarding Portugal, radio has been analyzed since 1997 with a "relatively modest status", being a "more or less neglected" medium (Oliveira, 2015, p. 239). Despite this, and the many perspectives that were taken to analyze radio, CR has never been considered as a scope of research. It may be due to its complexity as a medium with a strong digital presence, or perhaps because it is a recent phenomenon in Portugal. In fact, its digital presence is almost exclusive, having occasional FM frequencies assigned to them (Ribeiro, 2013). Such assignments happen for a limited period of time, when CR work is associated to cultural events, and last for half a year, maximum (Anselmo Canha, Personal Interview, 2015) ${ }^{1}$.

Portuguese radio has been analyzed mainly from the informative point of view and for its connection to the proximity and local communication, as we can see in the work developed by Luís Bonixe (2012, 2014, 2017), but also for its connection to sound and the role it represents in radio news and cyber news (Reis, 2015), and by its presence on the web, regarding its interactive and digital potential (Portela, 2011; Santos, 2015). Other areas of scientific approaches to radio studies are historical, such as the ones addressed by Paquete de Oliveira (1992), Paula Cordeiro (2003), or Rogério Santos (2003; 2012); the investigations carried out by Sílvio Santos (2013) about public service broadcasters; and those that broadly mention CR, such as this work by Filipe Reis (2006) named "As comunidades radiofónicas: um estudo etnográfico sobre a radiodifusão

\footnotetext{
${ }^{1}$ For example, Radio Manobras, in Oporto, sporadically has an FM frequency, but we can't consider it as theirs. Although this station is broadcasting its programming, legally the frequency is assigned to a local cultural or sports association, for a period of 6 months, which can be extended up to one year.
}

Copyright (c) 2021 by authors; licensee OJCMT. This article is an open access article distributed under the terms and conditions of the Creative Commons Attribution License (http://creativecommons.org/licenses/by/4.0/). 
local em Portugal" [The radio communities: an ethnographic study on local broadcasting in Portugal] ${ }^{2}$. Other works focus on the public participation in this media (Ribeiro, 2013), and pirate radios (Costa, 2017; Reis, 2014).

The scope of our study highlights the definition and mapping of Portuguese CR, in order to fulfill a muchneeded identification of the radio projects that present themselves as community projects, or that have characteristics that identify them as such.

\section{COMMUNITY RADIO: A DIFFICULT CONCEPT TO DEFINE}

Community radio assumes numerous nomenclatures all over the planet, and it can even be a "dangerous adventure", as Papa Dieng (2013) says, to try a definition, since its theoretical attributes may be different from what is then found in practice.

In the literature, it is common to find the following designations: community radios (Dieng, 2013; Fraser \& Restrepo-Estrada, 2001; Lewis \& Booth, 1989; Pavarala, 2015; Zuculoto, 2005), loudspeaker radios ${ }^{3}$ (Peruzzo, 2009), niche radios (Meda Gonzalez, 2014); pirate radios (Lewis \& Booth, 1989; Scifo, 2014) or free radios (Girard, 2002; Peruzzo, 2009). CRs were brought from the US to Europe (Scifo, 2014) and the adoption of nomenclatures varied depending on the country or region. In the UK and Spain, the term "community" was chosen from the beginning, but in countries such as Italy, Germany, or France, the emphasis fell on the terminology "free". In the Netherlands they were called "local" and in Scandinavian countries they were considered as "neighborhood and proximity radios" (Scifo, 2014, p. 164).

There are several denominations, profiles, and purposes, some appearing in remote villages in the countryside, others in neighborhoods of the world's largest metropolises. Some are characterized by being non-profit or cooperative, but there are also community radios linked to municipalities, churches, and unions. Others are funded by the audience itself and the content producers, by international development agencies, however, there are also situations where they are funded by advertising and governments (AMARC, 2015) ${ }^{4}$.

To support the development of a general definition of $C R$, it is necessary to detail some of the main characteristics that, crossing the largest number of authors dedicated to the study of this sector of broadcasting, are present in any of the aforementioned references.

A community broadcaster necessarily has a programming linked to the local reality, addressing the problems, commemorations, needs, interests and culture of that same locality (Zuculoto, 2005), and should provide the direct participation of the community in its management, in order to democratize the power to communicate, which should be characteristic of this medium (Peruzzo, 1998), making it a promoter of a participatory citizenship (Portela, 2011).

One of the essential principles commonly accepted is the need for there to be a collective ownership and management by a group of citizens who have a common goal, because "whatever the origin of the initiative, the radio is created by a community that is called, at the same time, to participate in its management" (Dieng, 2013, p. 6).

It should be kept in mind that one of the most distinctive criteria of a CR is its non-profit purpose, in order to maintain its exemption and impartiality, but it is also the most difficult criterion to respect due to issues of maintenance and financial survival (Dieng, 2013).

The development of a definition, but also of legal recognition and social importance, has been promoted by UNESCO, which, since the 80s of the last century, has developed a continuous work of promotion, implementation and support to broaden the spectrum of existing broadcasters around the world, so that they allow, in a structured way, to support communities on what to say and to whom to address, mirroring the local reality.

This communication of local realities allows breaking the barriers of isolation and illiteracy, often affirming CR as the means of communication of the poorest (Fraser \& Restrepo-Estrada, 2001). A communication for

\footnotetext{
${ }^{2}$ Mentioned in Oliveira, M. (2015). Som em frequência moderada: cartografia de estudos de rádio em Portugal [Moderate frequency sound: cartography of radio studies in Portugal]. In M. Oliveira \& N. Prata (eds.), Rádio em Portugal e no Brasil: trajetória e cenários (pp. 239-249). CECS - Centro de Estudos de Comunicação e Sociedade da Universidade do Minho.

${ }^{3}$ The original term adopted in Brazil is rádio altifalante.

${ }^{4}$ https://amarceurope.eu
} 
the development of the most marginalized populations which, when associated with the strong growth that these media have seen throughout the twentieth century all over the planet, has enabled the democratization and decentralization processes in several countries, as well as the decrease of state monopolies in the media panorama and the disaffection towards commercial radios. Citizens, especially the most disadvantaged, can participate in the communication process, "breaking their state of apathy and stimulating them to mobilize and organize in order to help themselves" (Fraser \& Restrepo-Estrada, 2001, p. 1). A stimulus that provides greater internal cohesion and community awareness, which is essential for the creation of a CR, and is even considered more fundamental than the technical skills and quality of citizens (AMARC, 2015; Dieng, 2013; Fraser \& Restrepo-Estrada, 2001; Paula, 2012).

\section{ONLINE RADIO'S POTENTIAL AS A SPACE FOR COMMUNITY PARTICIPATION}

Throughout history, after surviving many death predictions, radio is still facing a major challenge: to find a space within the newest and ever-changing media ecosystem. This (new) space will depend on its present and future ability to adapt to this new ecosystem (Cebrián Herreros, 2001, 2008).

The use of the internet by radio started as a mere instrument to replicate what the medium was broadcasting on FM. Only later, in a second phase, did it move towards the creation of Internet broadcasters, mainly to solve the problem of legal restrictions in some parts of the world (Portugal and the community radios are an example). "From the internet anyone can create their own broadcaster, although initially these broadcasters copied the same models as traditional radios" (Cebrián Herreos, 2010, p. 3)5

In a third, more recent phase, the Internet acquires another type of planning, either at the level of programmes or in the sections of each programme, which allows the user to search for the information he wants and choose the one that suits him best. And this choice may be interactive. An interaction that can happen with technology, with information and even through dialogue or debate of contents with other users (Cebrián Herreros, 2008).

This future can be viewed with "moderate optimism" (Santos, 2015), if it lives up to some of its fundamental characteristics, "such as immediacy, low cost or mobility" (2015, p. 93). Such relates directly to the Internet, for it has brought a set of opportunities to what can be spoken radio, and many more threats to what music radio is (Costa, 2017). The Internet changed what were the traditional radio concessions, including, for example, transmitted information in written and visual formats: "Internet radio is something other than radio" (Cebrián Herreros, 2001, p. 21) because it creates a platform for new approaches, new models of interactive communication, new uses, and the exchange of roles between users-promoters and users-receivers (Cebrián Herreros, 2008).

The internet has affected the landscape of radio, opening up broadcasting to a diversity of platforms and authors (Glevarec, 2014). In the case of radio, the main effect was the media convergence caused by new digital media (Lazer, 2013). This media convergence is about the interconnection between information, communication technologies and media content, which causes a structural change with direct implications in content and creativity (Lazer, 2013).

For example, other ways of making content available have emerged, such as online broadcasting, streaming and podcast. Online broadcasting, theoretically, enables the transmission of new content, different from those that were broadcast on-air on FM. Streaming allows the listener to hear the audio they want and when they want it, in real time on the internet. The podcast, on the other hand, allows the listener to download the content and listen to it on the platform of his choice and when he wants (Spinelli \& Dana, 2019).

The confluence of traditional radio with technical innovations and multimedia tools has given way to a renovation of language, content and the radio model itself. In other words, the challenges this media faces impose the need to adapt to a new notion of temporality, to a greater diversity in the availability of content, and also to the aesthetic modification of the sound language, given the decrease in FM radio listeners and the

\footnotetext{
5 In interview to Lucia Casajús - The Internet is an enormous complexity of communicative processes. https://www.researchgate.net/publication/277990798_Entrevista_a_Mariano_Cebrian_Herreros_Internet_es_una_enorme_ complejidad_de_procesos_comunicativos
} 
consequent increase in their online listening (Santos, 2015). Pedro Portela (2011), after Brecht, quoted by Zuculoto (2005), suggests the idea that there is "a kind of rebellion from the listener" (2011, p. 41) with New Information and Communication Technologies, since these new tools enable the listener to become a content producer, for it creates a favorable context for citizen participation. The listener becomes an observing, commenting, and producing agent, with more choice and decision-making (McChesney \& Nichols, 2016). This new form of participation is provided by the digital media and the community media and is the opposite of the reality that we can observe in the private mainstream media, focused on the market, where we find mostly a passive audience, poor interaction with their listeners and that excludes minority audiences (Carpentier, 2017; Higgins, 2008).

Listeners' participation and the existence of a more active audience online are two of the consequences of the change in the radio model, brought by its interactive capacity, where there is a permanent dialogue with the audience. This dialogue provides a guidance throughout the themes and decisions to be addressed, following the main interests of the listeners (Cebrián Herreros, 2001).

Such interactivity should allow the listener (web user) to search for the contents of one's own interest at any time and wherever one wishes. This interactive process will only be total though, if there is a capacity for dialogue with the source of information and if an exchange of information takes place between everyone.

This radio, open to participation, more personalized, tailored to each one (Herreros, 2001, p. 119), reaches more easily the goals of proximity towards the communities in which it operates. The proximity of local radios is reinforced, because they have very specific characteristics and conditions for the community to review itself in its programming (Bonixe, 2017).

In the European context, web radio (online radio) has been used as a teaching platform in virtual learning environments, being "responsible for the dissemination of various activities, which are developed in schools or universities, with programs dedicated to music, theater, cinema, education, science, technology, politics, poetry, literature, economics, current news and others" (Mendonça \& Duarte, 2010, p. 156). The same authors denote that in an academic environment, "works as a vehicle of social communication of local communities and as a valuable space for the dissemination, socialization and popularization of science and technology, produced by different departments in educational institutions" (Mendonça \& Duarte, 2010, p. 156). This assumption gives online radio a communicative potential, but at the same time educational, transversal to what community radios also intend to be.

The global world powered by the internet does not disappear with the promotion of local cultures and local content made possible by (local) radio. With the Internet, what is local does not only relate to its territorial dimension and is now accessible anywhere in the world. In other words, local becomes global. This happens because of the inherent ontological function in local radios, according to researcher Luís Bonixe (2017, p. 4950): "[...] despite the various emerging and technology-determined communication models, the local media still have a very strong bond with their communities [...] [thus, it] maintains the ontological function of connecting with local communities". Nevertheless, media participation in general, and mainstream radio in particular are still limited.

The phenomenon of CR has been analyzed as an alternative to public and private broadcasting, in different perspectives: whether as media with a strong social focus, claiming the rights of minorities and presenting themselves as platforms for social or economic development (Paula, 2012), particularly in underdeveloped or developing countries; or media with a more cultural focus, being an alternative to mainstream media, as is the general overview of the European case (Downing, 2001; Girard, 2002).

International institutions attach importance to CR and their social role. The European Union (European Parliament and the European Commission), for instance, issued a set of rules that pressure the governments of its member countries to legislate the third broadcasting sector, to which these radios belong. Other institutions such as AMARC - the World Association of Community Radios - and UNESCO, also study this sector, and support the implementation of community radio stations, particularly in Africa ${ }^{6}$. These institutions

\footnotetext{
${ }^{6}$ See AMARC Europe (2015) - <https://amarceurope.eu>
}

Fraser, C., \& Restrepo, S. (2001). Community Radio Handbook. UNESCO Digital Library <https://unesdoc.unesco.org/ark:/48223/pf0000124595>, April 2016. 
present these radios as an alternative to mass media, and as an important factor in the development of local communities, which are more open to participation. However, in Portugal, these radios have yet no legal framework, and so it is practically impossible to obtain a broadcast frequency in hertzian waves. Therefore, the only possibility remains on the potential of online broadcasts (Ribeiro, 2014, 2015).

Proximity communication with communities has been developed by local radios since the end of the twentieth century, after the regulations of 1988/1989. However, these radios are in an increasingly complex situation, following the result of recent policies for the sector and the economic hardship with less and less publicity (Bonixe, 2012, 2017; Costa, 2017; Reis, 2014). In spite of these difficulties, this context may also open the possibility for CR to expand, as it implements a wider participatory space, truly inherent in their nature.

\section{PROSPECTING A CHARACTERIZATION OF PORTUGUESE CR FRAMED IN THE INTERNATIONAL CONTEXT}

Based on an exhaustive literary review of CR in the various world geographies and how various authors approached this subject, we have established a set of criteria that we consider essential for the analysis and characterization of Portuguese community audio projects. This set of criteria is presented in Table 1 and was made by gathering the contributions of Lewis and Booth (1989) and Valerie Alia (2006) in North America; Cicilia Peruzzo (2009), Gumucio-Dagron (2005), Leal and Ribeiro (2007), Lílian Bahia (2005), Orlando Berti (2013) and Valci Zuculoto (2005) in South America; the researches of Fraser and Restrepo-Estrada (2001), Papa Dieng (2013) or Patrícia Paula (2016) in Africa; Inês David (2016), Malki (2006), MJR David (2002) and Rezaul Islam (2016) in Asia; also Janey Gordon (2012), Miriam González (2014), Price Davis and Tacchi (2001) and Salvatore Scifo (2014) in Europe; and finally the studies of Matt Mollgard (2018) and Tom Loncar (2010) in Oceania.

It brings together nine general characteristics that are divided into several specific idiosyncrasies: broadcasters' ownership, management, goals, revenue sources, mission, contents, identification of content producers and how they get involved, training provided to their staff, and accessibility towards the communities. From this set of characteristics, we can study the involvement and participation of communities in these media.

First of all, we must present our definition of community radio based on the study of these authors: these stations must be non-profit, despite in some cases they are allowed to raise some publicity, however on a small scale. Participation must be open to the community, allowing it to produce contents and participate in the management of the media. Regardless of gender, age, ethnicity or culture, these media must be available to all who want to participate, allowing dialogue and the development of a democratic process, which results in a context of good governance. One of its main features is to promote the local identity and the diversity of different cultures and languages. These media must also enable the training of their human resources, who are mostly volunteers, although, in some cases, there may also be employees.

Another characteristic of these media is the fact that they usually have licenses for low-power and shortrange FM frequencies, but, as we see later, this doesn't happen in Portugal, where these community stations exists exclusively online.

About the Portuguese reality, this information is obtained through the analysis of their digital presence (websites and social networks) and is complemented by interviews and questioning the volunteers of these radios, where information was insufficient. These volunteers are the ones who create the program schedule, control the broadcast, debate the programming content, and somehow coordinate the rest of the volunteer team that runs the radios.

This table is built according to some characteristics and features already studied by the mentioned authors. 
Table 1. Main Characteristics of Community Radios

\begin{tabular}{|c|c|c|}
\hline General Features & Specific Aspects & Authors \\
\hline \multirow[t]{3}{*}{ Property } & Held by a group of citizens & Dieng, $P$. \\
\hline & Foundation, association or cooperative & $(2013)$ \\
\hline & Nonprofit community, foundations, and associations & Fraser, C., \& \\
\hline \multirow[t]{3}{*}{ Management } & Active participation of the community & Restrepo, S. \\
\hline & For a common benefit & (2001) \\
\hline & Through the constitution of a community council & Peruzzo, C. \\
\hline \multirow[t]{5}{*}{ Goals } & A community-based communication goal & (2009) \\
\hline & Giving voice to minorities and who don't have voice in the mainstream media & Zucoloto, V. \\
\hline & Safeguarding local interests and/or linguistic diversity & (2005) \\
\hline & Means of literacy & NFCB (2016) \\
\hline & Contribution towards local development & AMARC \\
\hline \multirow[t]{5}{*}{ Revenue Sources } & Nonprofit & $(2015)$ \\
\hline & Sponsorships and/or advertisement & Price, D., \& \\
\hline & $\begin{array}{l}\text { Funding can come from donations of the community, radio members and/or the } \\
\text { audience }\end{array}$ & $\begin{array}{l}\text { Tacchi, J. } \\
(2001)\end{array}$ \\
\hline & State/ international organizations financing & Alia, V. \\
\hline & Funding from fundraising events & $(2006)$ \\
\hline \multirow[t]{2}{*}{ Broadcast range } & Low power & Paula, P. \\
\hline & Limited to $10 \mathrm{~km}$ radius & $(2016)$ \\
\hline \multirow[t]{3}{*}{ Contents } & Community-related information & \\
\hline & Diversity and plurality & \\
\hline & Local reality & \\
\hline \multirow[t]{5}{*}{ Producers } & Active communication in content creation and programming & \\
\hline & Plurality of voices & \\
\hline & Active role of the audience as producer/listener (broadcast) & \\
\hline & Active role of the population on radio programming & \\
\hline & Use of volunteers in broadcasts & \\
\hline \multirow[t]{2}{*}{ Staff Training } & Workshops and activities of contact & \\
\hline & Technical development of human resources & \\
\hline Accessibility & $\begin{array}{l}\text { Promotion of democratic processes through accessibility and participation in the } \\
\text { decision-making of broadcasts }\end{array}$ & \\
\hline
\end{tabular}

\section{IDENTIFICATION OF PORTUGUESE COMMUNITY RADIOS}

Looking at the analysis of the third Portuguese broadcasting sector, we could identify the community radio projects present in the online space and take into consideration their aim towards geographic communities or communities of interest (Anderson, 1983), and their inclination to participate while using the Internet as a preferred way to communicate.

Using a bibliographic research focused on Portuguese authors who investigate the radio in general, we identified these projects, particularly those that analyze its proximity (Bonixe, 2012; Bonixe 2017; Costa, 2017; Ribeiro, 2014, 2015; Oliveira, 2017), and those that focus on its connection to the digital world (Portela 2011; Santos, 2015).

This search was complemented by a simple research on browsers like Google, Yahoo and Sapo, using keywords such as: Rádio Comunitária", "Rádio Comunitária portuguesa", "Projeto de rádio comunitária", Projeto áudio online", "Terceiro setor de radiodifusão nacional”, "Projeto Comunitário de rádio", "Rádios das minorias" ou "Projeto rádio online"7.

Between the beginning of 2015 and the end of 2018, from the combination of these surveys, we compiled a list of 35 Portuguese radio projects with a digital presence, with possible community. After the first search results some of the projects that came out were not considered, because they didn't indicate any form of contact or analysis, such as site, blog, social media presence, online issue or podcasts. Furthermore, we found mentions to community webradio Ás (created in Aveiro in 2011) and to Jornalismo Porto Radio (created in Oporto in 2006), but we excluded these projects of our research scope because they do not exist anymore.

\footnotetext{
7 “Community Radio", “Portuguese Community Radio", “Community Radio Project", “Online Audio Project", "Third Sector
} National Broadcasting", "Minority Radios" or "Online Radio Project". 
Table 2. Community radio projects with digital presence

\begin{tabular}{|c|c|c|c|c|}
\hline CR Projects & Location & $\begin{array}{l}\text { Founc } \\
\text { Date }\end{array}$ & Involved Community & Focus \\
\hline Rádio Zero & Lisbon & 2004 & ISCTE & University students \\
\hline Rádio Manobras & Oporto & 2011 & Aleixo & $\begin{array}{l}\text { Social inclusion and civic } \\
\text { participation }\end{array}$ \\
\hline Stress FM & Lisbon & 2011 & Mouraria & $\begin{array}{l}\text { Social inclusion and civic } \\
\text { participation }\end{array}$ \\
\hline Quase FM & Lisbon & 2011 & Católica University & University students \\
\hline Engenharia Rádio & Oporto & 2007 & Oporto University & University students \\
\hline Rádio Aurora & Lisbon & 2009 & $\begin{array}{l}\text { Psychiatry - Júlio de } \\
\text { Matos Hospital }\end{array}$ & Social - Health \\
\hline UALMedia Rádio & Lisbon & $\mathrm{NI}$ & Autónoma University & University students \\
\hline ESCSFM & Lisbon & 2010 & ESCS students & University students \\
\hline Rádio Radical & Lisbon & 2011 & $\mathrm{NI}$ & $\mathrm{NI}$ \\
\hline RUBI - Rádio Universidade da Beira Interior & Covilhã & 2003 & UBI students & University students \\
\hline NRC - Net Rádio Católica & $\begin{array}{l}\text { Moita } \\
\text { (Setúbal) }\end{array}$ & 2006 & Catholics & Religion \\
\hline CC FM & Oporto & 2012 & UP students & University students \\
\hline Cascais Net Rádio & Cascais & 2014 & $\mathrm{NI}$ & $\mathrm{NI}$ \\
\hline Rádio Lusitânia CB & Alentejo & 2006 & $\mathrm{NI}$ & $\begin{array}{l}\text { Culture - Portuguese } \\
\text { language }\end{array}$ \\
\hline Rádio Miúdos & Bombarral & 2015 & $\begin{array}{l}\text { Portuguese speaking } \\
\text { African countries }\end{array}$ & $\begin{array}{l}\text { Culture - Portuguese } \\
\text { language }\end{array}$ \\
\hline Rádio Active 101 & All Country & 2013 & Marginalized groups & $\begin{array}{l}\text { Social inclusion and civic } \\
\text { participation }\end{array}$ \\
\hline RRE - Rádio Refúgio Emigrantes & Madeira & $\mathrm{NI}$ & $\begin{array}{l}\text { Portuguese speaking } \\
\text { community }\end{array}$ & $\begin{array}{l}\text { Social - immigrants and } \\
\text { emigrants }\end{array}$ \\
\hline Rádio Baixa & Coimbra & 2018 & Downtown & Music \\
\hline Rádio Quântica & Lisbon & 2015 & $\begin{array}{l}\text { Artists and cultural } \\
\text { activists }\end{array}$ & Music \\
\hline Rádio Escuta & Lisbon & 2018 & Intendente & $\begin{array}{l}\text { Social inclusion and civic } \\
\text { participation }\end{array}$ \\
\hline Rádio Transforma & Oporto & 2018 & Oporto City & $\begin{array}{l}\text { Social inclusion and civic } \\
\text { participation }\end{array}$ \\
\hline
\end{tabular}

Nonetheless, webradio Ás keeps an active digital address and is presented as a community communication project created by the municipalities of Aveiro in Portugal, São Bernardo do Campo in Brazil, and Santa Cruz in Cape Verde to motivate civic participation, strengthen community cohesion and explore local identity. According to Fábio Ribeiro (2014) it was extinguished two years after its creation, and we confirm its inactivity: absence of online broadcast and no information updates on the website. Also, Terras de Santa Mafalda radio, Braga DJ radio, Radio Control FM, or Radio Immigrant are not included in our study due to lack of information. Jornalismo Porto Rádio got replaced by CC FM.

Wit FM is also excluded, for it is linked to a private company (software) and does not fit into our paradigm of a community project. Despite the sporadic participation of company members, it was created by the company itself, that still owns and manages it.

Rádio Zigzag is also excluded because is streamlined within the RTP group - Radio and Television of Portugal, thus it belongs to the public broadcasting sector, and cannot be considered a community audio project.

Considering these exclusions, our first analysis focuses on the areas of the country where the 21 projects emerged, and which remains under investigation. It is clear that Portuguese community audio projects with exclusively online broadcast exist mainly in the two largest metropolitan areas: Lisbon and Oporto. These areas present a greater focus on chain broadcasts by local radios, as it appears there was a detachment of a local identity, being these "territories with more market and audience potential" (Costa, 2017, p. 58). By starting a chain transmission, a contradiction takes place: while local radios break the connection, they kept with the communities, and shut themselves to the listeners' participation, something new emerges. From the 
void where no participation happens, another spot of opportunities stands out, and a new CR is made, thus setting a new relationship with local communities as a place for public discussion reappears.

This tendency towards a disappearance of local radio stations brings us "a country divided in two, with the coast where local radios were thinning and the interior, where there are still local radio projects that are very interesting, with sites, news, debates and interaction with communities" (Costa, 2017, p. 97).

All projects listed here have emerged in the $21^{\text {st }}$ century. There are indications that the Zero radio, which operates at ISCTE - University Institute of Lisbon, has been the first to broadcast in Portugal, in 2004. However, the first experiments for this type of radios started in 1997 by Engenharia Rádio, which only in 2007 begins to broadcast regularly. It is important to highlight that, only in 2018, three community radio stations, with no hertzian frequency, appeared in Coimbra, Lisbon and Oporto. One can infer there is a growing tendency towards this kind of projects.

Most of these projects relate to university student communities as target audience, calling for the students' participation, and emerged among universities or other higher education institutions. These online radio projects aren't registered on ERC (the Portuguese communication regulatory entity) ${ }^{8}$.

However, we cannot confuse these projects with portuguese university radios, which are recognized as local radios, that have a FM frequency, and legal status recognized by the n. ${ }^{\circ}$ 54/2010 law.

There are also radios that focus on social and cultural issues, and are linked to specific areas, groups or neighborhoods (namely Lisbon or Oporto). These focus on social inclusion and active citizenship. For instance, Rádio Aurora - a outra voz stands out by approaching health-related topics, especially psychiatric illnesses. Other examples relate to cultural and activism purposes - Rádio Quântica is a participation space for artists that do not fit in mainstream radios to broadcast and share their art and music.

\section{COMMUNITY RADIOS - A PORTUGUESE CASE STUDY}

It is evident that these exclusively online Portuguese radios follow an international pattern: their creation is directly related to a group of citizens. Either they are based on such communities or call for their involvement somehow. The geographic communities - especially in local neighborhoods in Lisbon and Oporto - assure their presence and purpose through the communication of an ideal or project, or by giving voice to a social group. Normally, these nonprofit radio projects emerge from the will and hard work of a group of volunteers that unite towards a common purpose: creating and promoting a community-based radio.

Regarding ownership, or what motivates the formation of these radios, since they are created by a group of citizens without any legal representation, some radios assume, after some time, the legal framework of an association. As we stated before, many of these projects are linked to higher education student associations, so we stress that these are connected to higher education communities (university or polytechnic institutions). Plus, among these are several cases related to degrees in Communication and Journalism areas. An exception is Engenharia Rádio (1997), the pioneer project from the Faculty of Engineering of the University of Porto (Oporto). Naturally, the projects comply with the students' participation. The issues broadcasted and discussed range from the strictly academic to social and cultural news and subjects.

In the beginning of the new millennium, online radios focused on higher education student communities, but in a second phase, starting in 2010, we can see the emergence of radio stations with a greater social nature (that is, regarding social, cultural and political intervention), such as Rádio Manobras (2011), RadioActive101 (2013), Rádio Quântica (2015), Rádio Escuta (2018) and Rádio Transforma (2018).

\footnotetext{
${ }^{8}$ ERC - Entidade Reguladora para a Comunicação Social (Regulatory Authority for the Media) was established by Law 53/2005, of November 8th, 2005, having commenced its duties with the inauguration of the Regulatory Board on February 17th, 2006. Its main objective is the regulation and supervision of all entities that perform media activities in Portugal. The ERC is constituted by the Regulatory Board, responsible for the definition and implementation of the regulatory action; by the Executive Board, which has as its functions the direction of the services, as well as the administrative and financial management; by the Consultive Council, body for consultation and participation in the definition of the general lines of action of the ERC; and by the Statutory Auditor, who controls the legality and efficiency of the financial and patrimonial management of this entity. https://www.erc.pt/documentos/legislacaosite/lei53.pdf
} 
These Portuguese CR projects start with the active participation of one or more citizens who, through an active management of the radio, involve the rest of the community. In all the projects we examined, it was evident an awareness on an increasingly plural participation. Hence the content production became plural too, for it meant that the audience was active and proactive by listening and producing different contents.

In general, these projects are focused on the communities from which they emerged. This means that everyone in the community have access to the broadcast and serves as a recognition that this greater participation promotes a democratic process, where everyone is free to participate, including minorities, as it gives them a space to voice their concerns and speak up, contributing towards social inclusion and receptiveness.

Participation plays an essential role in the field of communication and media studies, especially by addressing the dialectic passive audience/active audience (Carpentier, 2017). Community participation and interaction are understood as an inherent characteristic of an active audience. However, this type of participation cannot be analyzed as mere access and interaction with the media organization because these concepts should not be studied without the power and decision-making dynamics. Nico Carpentier (2017) defines three participatory dimensions in the media by an active audience: a) participation in media production; b) participation in society through the media; and c) interaction with the media content.

From our analysis of the mentioned $\mathrm{CR}$, we can conclude that these three participatory dimensions are brought together. Though more data and research are needed to draw further insights, using the qualitative methodology of case studies. Nonetheless, it is clear that the communities that gave rise to these radio projects are open to everyone's participation regarding the assembling of programmatic grids, the management of the media, and the content production. This leads to an active participation in the social construction and cohesion of the community in which they operate, particularly in projects from higher education institutions.

Through CR, citizens become closer to local and community issues. These media contribute to the public debate on issues that tend to be ignored by the mass media - for instance, the CR project Rádio Aurora created at Júlio de Matos Hospital, in Lisbon, aims to bring to the public space the theme of mental health.

Historically, evidence shows that public debate involves a limited number of citizens, with higher education and easier access to the media. Nowadays, a younger, more digital and online-oriented social layer of population demand and achieve easier and faster access to both mass and new media, thus creating a suburbanization of the sphere. In other words, this fragmentation of the audience is connected with multiple and divided forms of production provided by new technologies (Silverstone, 1999), that somehow bring a sense of togetherness, as it functions as a social glue. This happens because of the people involved in these projects, who convey certain contents or messages via CR that enhance or influence good decision-making by the local government (Downing, 2001).

Finally, the producer networks that form around community audio projects enable user empowerment, and can be used to give voice, hope and expectations to groups and communities, creating an ideal of participatory democracy (Proulx et al., 2011). It is also important to detail that this active participation also has consequences for the mass media themselves, which are forced to seek adaptation and even reinvention, due to these new participation trends brought on by the new millennium, regarding technological innovation and development and the growth of digital media (Nyre \& Ala-Fossi, 2010).

Although this article is the result of an early phase of further study of possible Portuguese CR projects, our research indicates that there is a strong participatory potential of this third broadcasting sector, which in Portugal is developing exclusively online due to a legal vacuum. The Portuguese Radio Law (No. 54/2010) considers and regulates public service radios (first sector) and private service radios (second sector), but no reference to community projects is stated, which prevents the allocation of frequency in FM. This means there is liberty towards a development of CR. Plus, the many possibilities offered by new technologies allow communities to gather around common issues and interests by participating in the media through their own community radio projects.

Author contributions: All authors were involved in concept, design, collection of data, interpretation, writing, and critically revising the article. All authors approve final version of the article.

Funding: The authors received no financial support for the research and/or authorship of this article. 
Declaration of interest: Authors declare no competing interest.

Data availability: Data generated or analysed during this study are available from the authors on request.

\section{REFERENCES}

Alia, V. (2006). Indigenous radio in Canada. In A. Crisell (Ed.), More than a music box - Radio cultures and communities in a multimedia world (pp. 77-94). Berghahn Books.

Anderson, B. (1983). Imagined Communities - Reflections on the Origin and Spread of Nationalism. Verso.

Bahia, L. (2005). Potencialidades e limitações de rádios comunitária e educativa da região metropolitana de Belo Horizonte [Potential and limitations of community and educational radios in the metropolitan region of Belo Horizonte]. Livro de Actas do $4^{\circ}$ SOPCOM - Congresso das Ciências da Comunicação, Porto. http://www.bocc.ubi.pt/pag/bahia-lilian-potencialidades-limitacoes-radios-comunitaria-educativa.pdf

Berti, O. M. C. (2013). O perfil das rádios comunitárias nordestinas que estão na internet [The profile of community radio stations in the Northeast that are on the internet]. INTERCOM - Sociedade Brasileira de Estudos Interdisciplinares da Comunicação. http://www.intercom.org.br/papers/nacionais/2013/resumos/R8-0036-1.pdf

Bonixe, L. (2012). O local como especialização - as rádios locais portuguesas enquanto espaço para a comunicação de proximidade [The place as a specialization - Portuguese local radios as a space for proximity communication]. Repositórios Científicos de Acesso Aberto de Portugal. http://comum.rcaap.pt/bitstream/123456789/5287/1/Lu\%C3\%ADs\%20Bonixe.pdf

Bonixe, L. (2014). Rádio - Contextos e Linguagens [Radio - Contexts and Languages]. Media \& Jornalismo, 13(1).

Bonixe, L. (2017). As rádios locais portuguesas na transição para a Internet [Portuguese local radio stations in the transition to the Internet]. In P. Jerónimo (Ed.), Media e Jornalismo de proximidade na era digital (pp. 47-86). Labcom.

Carpentier, N. (2017). Media e Participação. Media XXI.

Casajús, L. (2010). Internet es uma enorme complejidad de procesos comunicativos [Internet is an enormous complexity of communication processes]. Interview to Mariano Cebrián Herreros. https://www.researchgate.net/publication/277990798_Entrevista_a_Mariano_Cebrian_Herreros_Intern et_es_una_enorme_complejidad_de_procesos_comunicativos

Cebrián Herreros, M. (2001). La radio en la convergencia multimedia [Radio in multimedia convergence]. Gedisa Editorial.

Cebrián Herreros, M. (2008). La radio en internet [Internet radio]. La Crujia.

Cordeiro, P. (2003). A rádio em Portugal: um pouco de história e perspectivas de evolução [Radio in Portugal: a little history and perspectives for evolution]. Biblioteca Online das Ciências da Comunicação. http://www.bocc.ubi.pt/pag/cordeiro-paula-radio-portugal.pdf.

Costa, P. (2017). Teias da Rádio: Ensaios e Reflexões sobre as políticas do setor [Radio Web: Essays and Reflections on Sector Policies]. CECS - Centro de Estudos de Comunicação e Sociedade da Universidade do Minho.

David, M. I. (2006). (Community) Radio for development in Timor-Leste [Master Dissertation, Faculty of Social and Behavioral Sciences, Leiden University].

David, M. J. R. (2002) Mahaweli community radio. In B. Girard (Ed.), Radio apasionados - experiencias de radio comunitária en el mundo [Passionate radio - community radio experiences in the world] (pp. 103-110). http://comunica.org/apasionados/pdf/radioapasionados.pdf

Dieng, P. (2013). Radio Communautaires, espace public et développement local: enjeux et contraintes au Sénégal [Community radio, public space and local development: challenges and constraints in Senegal]. Revue Electronique Internationale de Sciences du Langage - Sudlangues, 19, 43-67. http://www.sudlangues.sn/IMG/pdf/article_2_dieng.pdf

Downing, J. (2001). Radical media. Rebellious communications and social movements. Sage Publications.

Fraser, C., \& Restrepo, S. (2001). Community radio handbook. UNESCO Digital Library.

Girard, B. (2002). Radio Apasionados - Experiencias de radio comunitária en el mundo [Passionate Radio Community radio experiences in the world]. https://dpya.org/wiki/images/4/4c/Radioapasionados.pdf

Glevarec, H. (2014). Le propre de la radio. Fonctions radiophoniques et nouveau statut de la radio dans l'environnement numérique [The peculiarity of radio. Radio functions and the new status of radio in the digital environment]. Le Temps des médias, 22, 123-133. https://doi.org/10.3917/tdm.022.0123 
Gordon, J. (2012). The community media in the twenty-first century. Peter Lang Editions. https://doi.org/10.3726/978-3-0353-0251-6

Gumucio-Dagron, A. (2005). Miner's radio stations. A unique communication experience from Bolivia. In Media and glocal change: rethinking communication for development. CLACSO - Consejo Latinoamericano de Ciencias Sociales.

Higgins, M. (2008). Media and their publics. Open University Press.

Islam, M. R. (2016). NGO, social capital and community empowerment in Bangladesh. Palgrave, MacMillan. https://doi.org/10.1007/978-981-10-1747-6

Latzer, M. (2013). Media Convergence. In R. Towse \& C. Handke (Eds.), Handbook on the digital creative economy (pp. 123-133). Edward Elgar Publishing Limited. https://doi.org/10.4337/9781781004876.00022

Leal, S., \& Ribeiro, L. (2007). Mídias alternativas e esfera pública: democracia e reconhecimento nas rádios comunitárias no Brasil e na França [Alternative media and the public sphere: democracy and recognition in community radios in Brazil and France]. Estudos De Sociologia, 12(23), 65-96. http://seer.fclar.unesp. br/estudos/article/view/500

Lewis, P., \& Booth, J. (1989). The invisible medium. Public, commercial and community radio. Howard University Press. https://doi.org/10.1007/978-1-349-19984-6

Loncar, T. (2010). Community attitudes to radio content - research report prepared for the Australian communications and media authority. ACMA - Australian Communications and Media Authority, http://acma.gov.au

Malki, M. (2006). Community development approaches: a concept note. In Hamyaran (Ed.), Community empowerment for sustainable development in Iran (pp. 50-59). Iran NGO Resource Centre.

McChesney, R. W., \& Nichols, J. (2016). People get ready: the fight against jobless and a citizen democracy. Public Affairs.

Meda González, M. (2014). El tratamiento de los medios comunitarios en el marco de la ley general de la comunicación audiovisual [Doctoral dissertation, Universidad Complutense de Madrid].

Mendonça, M., \& Duarte, B. (2010). Rádio Web \& Podcast: conceitos e aplicações no ciberespaço educativo [Web Radio \& Podcast: Concepts and Applications in Educational Cyberspace]. Revista de Comunicación y Nuevas Tecnologías, 14, 253-261.

Mollgard, M. (2018). Access community radio in New Zealand. NZ on Air. https://d3r9t6niqlb7tz.cloudfront.net/ media/documents/2018-10_Mollgaard_Access_Radio_Review_2018_FINAL_for_publishing.pdf

Nyre, L., \& Ala-Fossi, M. (2010). Two-way radio: audience participation and editorial control in the future. In B. O'Neill (Ed.), Digital radio in Europe - Tecnologies, industries and cultures. Bristol.

Oliveira, M. (2015). Som em frequência moderada: cartografia de estudos de rádio em Portugal [Moderate frequency sound: cartography of radio studies in Portugal]. In M. Oliveira \& N. Prata (Eds.), Rádio em Portugal e no Brasil: trajetória e cenários (pp. 239-249). CECS - Centro de Estudos de Comunicação e Sociedade da Universidade do Minho.

Oliveira, M. (2017). A reconfiguração das rádios locais ou a ameaça da Frequência Localizada [The reconfiguration of local radios or the threat of Localized Frequency]. In P. Costa (Ed.), Teias da Rádio: Ensaios e Reflexões sobre as Políticas do Setor. CECS - Centro de Estudos de Comunicação e Sociedade da Universidade do Minho.

Paquete de Oliveira, J. (1992). A integração europeia e os meios de comunicação social [European integration and the media]. Análise Social, 27, 995-1024.

Paula, P. (2012). Comunicação para o desenvolvimento: novo paradigma de intervenção comunitária. Rádios comunitárias da Guiné Bissau e de Moçambique [Communication for development: a new paradigm for community intervention. Community radios from Guinea Bissau and Mozambique]. CIES-IUL - Centro de Investigação e Estudos em Sociologia, do Instituto Universitário de Lisboa. https://repositorio.iscteiul.pt/bitstream/10071/4266/1/CIES_WP133_Paula.pdf

Pavarala, V. (2015). Community radio "under progress". Resuming a paused revolution. Economic \& Political Weekly, 51. http://www.sancomonline.net/wp-content/uploads/2015/02/Community-Radio-UnderProgress-Vinod-Pavarala.pdf

Peruzzo, C. (2009). Rádios livres e comunitárias, legislação e educomunicação [Free and community radios, legislation and educommunication]. Revista Eletrónica Internacional de Economia Política da Informação e da Comunicação, 11(3). https://seer.ufs.br/index.php/eptic/article/view/98/70 
Portela, P. (2011). Rádio na Internet em Portugal [Internet radio in Portugal]. Humus Editions.

Price-Davis, E., Tacchi, J. (2001). Community radio in a global context: a comparative analysis in six countries. CMA - Community Media Association.

Proulx, S., Heaton, L., Choon, M., \& Millette, M. (2011). Paradoxical empowerment of producers in the context of informational capitalism. New Review of Hypermedia and Multimedia,17(1), 9-29. https://doi.org/10.1080/13614568.2011.552646

Reis, A. I. (2014). As rádios piratas em Portugal - contributos para um percurso [Pirate radios in Portugal contributions to a journey]. In A. Reis, F. Ribeiro \& P. Portela (Eds.), Das piratas à Internet: 25 anos de rádios locais (9-28). CECS - Centro de Estudos Comunicação e Sociedade da Universidade do Minho.

Reis, A. I. (2015). O áudio nas cibernotícias das rádios [Audio in cyber news radios]. Média XXI.

Ribeiro, F. (2013). A participação dos cidadãos nos média portugueses: estímulos e constrangimentos [Citizen participation in Portuguese media: stimuli and constraints] [Doctoral dissertation, University of Minho]. https://repositorium.sdum.uminho.pt/bitstream/1822/27212/1/Fábio\%20Fonseca\%20Ribeiro.pdf

Ribeiro, F. (2014). Recuperar o Espírito das Piratas: reflexões sobre rádios comunitárias em Portugal, do vazio legal a uma proposta concreta [Recovering the Spirit of Pirates: reflections on community radios in Portugal, from the legal vacuum to a concrete proposal]. In A. Reis, F. Ribeiro \& P. Portela (Eds.), Das Piratas à Internet: 25 anos de rádios locais (pp. 113-131). CECS - Centro de Estudos de Comunicação e Sociedade da Universidade do Minho.

Ribeiro, F. (2015). Rádios comunitárias na Galiza e em Portugal, o ruído e o silêncio: contraste de experiências na emergência de novos desafios sociais [Community radios in Galicia and Portugal, noise and silence: contrasting experiences in the emergence of new social challenges]. Repositórium da Universidade do Minho.

Santos, L. A. (2015). Rádio e Internet: o desafio pode começar de novo [Radio and Internet: the challenge can start again]. In M. Oliveira, \& N. Prata (Eds.), Rádio em Portugal e no Brasil: trajetórias e cenários (pp. 189202). CECS - Centro de Estudos de Comunicação e Sociedade da Universidade do Minho.

Santos, R. (2003). Rádio Clube Português - Da escassez de frequências à grande importância no meio radiofónico nacional (1931-1936) [Rádio Clube Português - From the scarcity of frequencies to the great importance in the national radio environment (1931-1936)]. Media \& Jornalismo, (3), 51-66.

Santos, R. (2012). A Rádio não tem emissão educativa. É essencialmente distração. Da tradição à modernidade radiofónica (1961-1969) [Radio has no educational broadcast. It's essentially distraction. From radio tradition to modernity (1961-1969)]. In O meio rádio e os 75 anos da Rádio Renascença [The radio medium and 75 years of Rádio Renascença]. Universidade Católica Portuguesa.

Santos, S. (2013). Os Media de Serviço Público [The Public Service Media]. Labcom.

Scifo, S. (2014). Communication rights as a networking reality: Community radio in Europe. In C. Padovani (Ed.), Communication rights and social justice. Global transformation in media and communication research (pp. 164-179). Palgrave. https://doi.org/10.1057/9781137378309_10

Silverstone, R. (1999). Why study the media?. Sage Publications.

Spinelli, M., \& Dann, L. (2019). Podcasting - the audio media revolution. Bloomsbury. https://doi.org/10.5040/9781501328671

Zuculoto, V. (2005). Debatendo com Brecht e sua teoria do rádio (1927-1932): um diálogo sempre atual sobre o papel social e as potencialidades da radiodifusão [Debating with Brecht and his theory of radio (19271932): an ever-present dialogue about the social role and potential of broadcasting]. Intercom Sociedade Brasileira de Estudos Interdisciplinares da Comunicação, $28^{\circ}$ Congresso Brasileiro de Ciências da Comunicação.

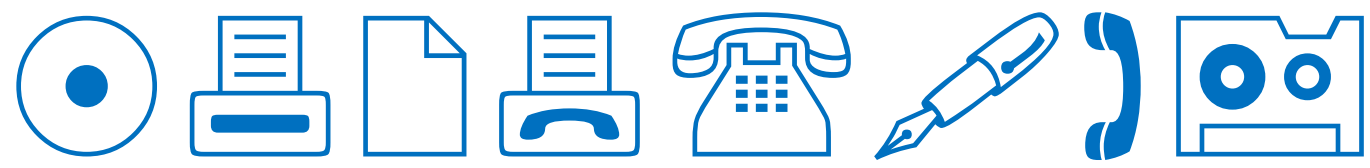

